\title{
COMPARATIVE STUDY OF ACHYRANTHUS ASPERA AND PHYLLANTHUS AMARUS FOR THE REMOVAL OF LEAD FROM POLLUTED WATER BY USING THEIR BIOSORBENTS POWDER
}

\author{
K. Jaya Prasanthi and A. Aruna Kumari \\ Department of Chemistry, \\ Bapatla College of Arts \& Sciences, Bapatla, \\ Guntur District - A.P. India.
}

\begin{abstract}
Lead metal is highly inert metal used widely because of its mechanical properties like high density, low melting point and ductility. Half of the lead produced is used as electrodes in lead acid car batteries, construction of buildings and pipes. Lead is poisonous to human beings if inhaled or swallowed. Achyranthus aspera and Phyllanthus amarus both the plants are widely available as weeds and they have excellent medicinal values. These plants are extensively used in folk, Ayurveda and Unani medicines. The leaves, stems, fruits, flowers and seeds cut from both the plants were washed with distilled water and dried in sun light. The dried materials were crushed and meshed to reduce the size of the particles below75 $\mu$ and activated at $100^{\circ}$ using hot air oven. At $\mathrm{pH} \mathrm{6}$, at the period of 7 days with maximum adsorbent dose seed ash and dry powders of P.amarus plant shown highest adsorption of lead $88.54 \%$ and $86.75 \%$ respectively. At the same conditions A.aspera's flowers ash and dry powders has shown $84.69 \%$ and $80.61 \%$ of lead adsorption from polluted water. The Bio sorbent powders are structurally analyzed with FT-IR spectroscopy before and after adsorption.
\end{abstract}

Keywords: Achyranthus aspera, adsorption, biosorbent powders, FT-IR, Lead, Phyllanthus amarus and removal.

Cite this Article: K. Jaya Prasanthi and A. Aruna Kumari, Comparative Study of Achyranthus Aspera and Phyllanthus Amarus for the Removal of Lead from Polluted Water by using their Biosorbents Powder, International Journal of Advanced Research in Engineering and Technology, 10 (6), 2019, pp 1-15.

$\mathrm{http}: / /$ iaeme.com/Home/issue/IJARET?Volume $=10 \&$ Issue $=6$ 


\section{INTRODUCTION}

\subsection{Lead}

Lead $(\mathrm{Pb})$ belongs to 14 th group element of the periodic table having atomic number 82 . It is a heavy and stable metal with silvery white or grayish colour ${ }^{1}$. When freshly cut, lead is bluish-white; it tarnishes to a dull gray color when exposed to air. Lead is soft, malleable, and has relatively low melting point. Lead metal is highly corrosive resistant that's why it is durable $^{2}$. Lead is extensively used in construction, plumbing, batteries, bullets and shot, weights, solders, pewters, fusible alloys, white paints, leaded gasoline, and radiation shielding due to its high density, low melting point, relative inertness to oxidation, its relative abundance and low $\cos ^{3-7}$. Lead widely used to make statues and sculptures ${ }^{8}$. It is also use in radiation shields around $\mathrm{X}$-ray equipment ${ }^{9}$. Lead has been used as a paint additive, in face whitening make-up, in water pipes, preservative for food and drinks, pesticide, and in paint used on children's toys.

Lead element is poisonous to human beings if inhaled or swallowed. Lead poisoning can cause various health disorders which vary depending on the individual and the duration of lead exposure. Exposure to organic Lead is probably more toxic than inorganic Lead due to its rapid lipid solubility. Poisoning by organic Lead compounds has symptoms predominantly in the central nervous system ${ }^{10}$. It can damage the body's organs and can cause weakness in the body's joints. Some symptoms of lead poisoning include nausea, vomiting, extreme tiredness, high blood pressure, and convulsions (spasms). Over a long period of time, children often suffer brain damage. They lose the ability to carry out normal mental functions. Lead poisoning occurs due to contamination of soil and water nearby industries, usage of lead pipes, lead paint and residual emissions from leaded gasoline ${ }^{11}$.

It is very essential to remove Lead from the polluted water because of above adverse effects, to prevent environmental pollution and human beings. Few research articles are available for the removal of Lead from the polluted water by using Achyranthus aspera and Phyllanthus amarus plants. Chandrakant D. Shendkar ${ }^{12}$ et al have developed efficient adsorption of $\mathrm{Pb}^{+2}$ and $\mathrm{Cd}^{+2}$ from polluted water by using A. Aspera adsorbents. Marques $\mathrm{P}$. Rosa ${ }^{13}$ et al have experimented on the effect of $\mathrm{pH}$ on the removal of $\mathrm{Pb}^{+2}, \mathrm{Cd}^{+2}$ and $\mathrm{Cu}^{+2}$. Genevieve Etomam Adukpo ${ }^{14}$ et al have done heavy metal analysis in Ghana area using P. Amarus biosorbents. Extensive research work is not done on the selected plants for the removal lead from polluted water.

\section{PLANTS DESCRIPTION}

\subsection{Achyranthus Aspera}

Achyranthes aspera commonly named as Uttareni, chaff-flower, prickly chaff flower, devil's horsewhip, is a species of plant in the Amaranthaceae family ${ }^{15-17}$. It is widely distributed on road sides, gardens, crops, grasslands, savanna and forest margins. Achyranthes aspera is an erect long-lived perennial herb which can grow up to $2 \mathrm{~m}$ tall. It stems become woody at the base, leaves are dark green above and paler below. They are opposite, simple and egg-shaped with broad end at base (ovate) up to $10 \mathrm{~cm}$ long by $8 \mathrm{~cm}$ wide, densely to sparsely hairy tapering to a point at both ends and shortly stalked ${ }^{18}$. The small greenish-white flowers have shown form narrow, elongated terminal spikes. As the flowers age, they bend downwards and become pressed closely against the stem. The bracts surrounding the flowers in the fruiting stage have sharp, pointed tips making the heads spiny to the touch ${ }^{19}$. The sharp-pointed fruits are orange to reddish purple or straw-brown capsules.

Achyranthes aspera contains triterpenoid saponins which possess oleanolic acid as the aglycone. ecdysterone, an insect moulting hormone, and long chain alcohols are also found in. 
Other chemical constituents such as achyranthine, betaine, pentatriaontane, 6pentatriacontanone, hexatriacontane, and tritriacontane ${ }^{20}$ are also present. Achyranthes aspera has occupied a pivotal position in Indian culture and folk medicine ${ }^{21,22}$. The tribal and rural people of India commonly use this herb in various disorders. In Uttar Pradesh, the plant is used for medicinal purposes, especially in obstetrics and gynecology, including abortion, induction of labor, and cessation of postpartum bleeding. The seeds are given in cases of snake-bites, as well as in ophthalmia and cutaneous diseases. The flowering spikes, rubbed with a little sugar, are made into pills, and given internally to people bitten by mad dogs. The leaves, taken fresh and reduced to a pulp, are considered a good remedy when applied externally to the bites of scorpions ${ }^{23}$.

\subsection{Phyllanthus Amarus}

Bhumi amla or Nelausiri or Bhuiamla botanically named as Phyllanthus amarus is an annual herb mainly growing in rainy season. The plant grows as weed in many places of America, Australia, South Africa and Asia ${ }^{24,25}$. It can be survives under tropical and high rainfall conditions and tolerates temporary water logging ${ }^{26}$. During rainy season, it grows abundantly in cultivated lands, waste lands, along roadsides and open areas ${ }^{27}$. The plant grows $20-75 \mathrm{~cm}$ height, branching profuse towards upper region bearing 5-10 pairs of leaves. Fruits are distributed underneath the leaves small smooth capsules which look like amla ${ }^{28}$. The plant extract has been found to contain high levels of saponins, tannins, flavonoids and alkaloids Phyllanthus amarus is an important herbaceous medicinal plant used in the traditional and folk medicines for the treatment of several diseases like jaundice, asthma, hepatitis, tuberculosis, ulcer and urinary diseases. It is also used in stomach ailments like dyspepsia, colic, diarrhea, dysentery, dropsy, urinogenital problems and for external application in case of swelling and inflammation ${ }^{29}$. This medicinal herb is widely used in Ayurveda and Unani medicins to treat various health problems. For medicinal purpose whole plant and roots are used. The plant is very rich in potassium due to which it is powerful diuretic. Therefore the authors selected these medicinal plants for this comparative study due to their high medicinal values and availability as weed. The developed method is novel, simple, eco-friendly.

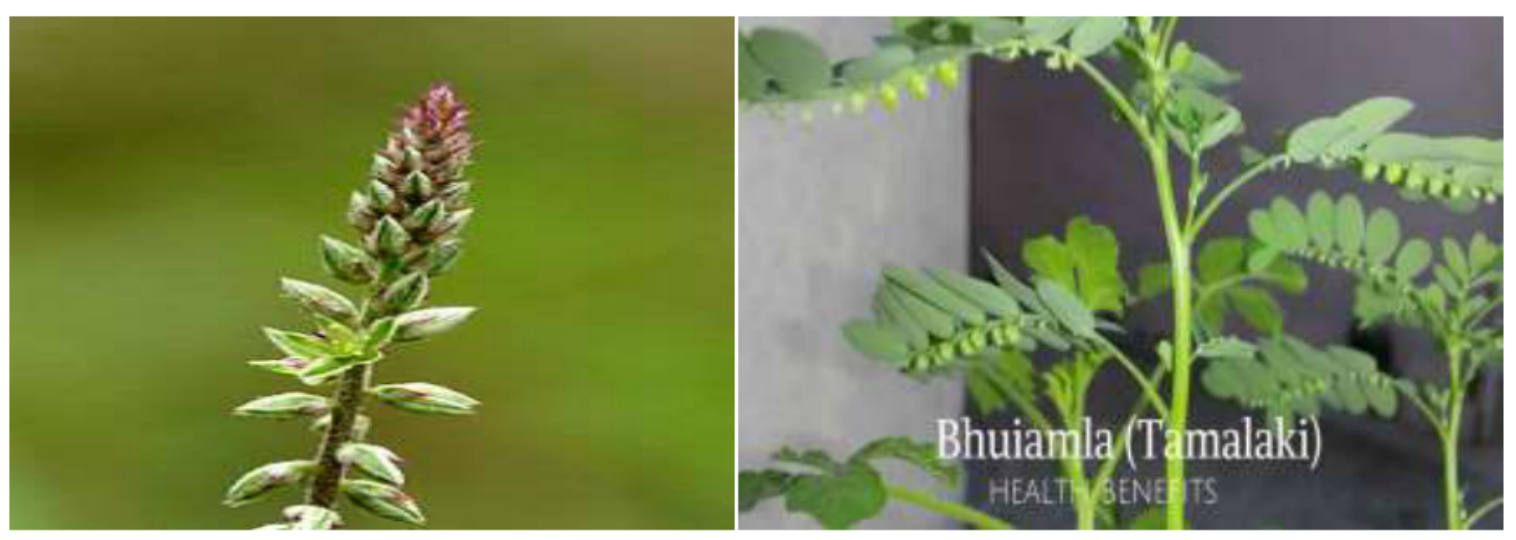

Figure 1. Achyranthus aspera and Phyllanthus amarus plants

\subsection{Objective of this method}

- Stems, fruits, leaves, seeds and flowers of the Achyranthus aspera and Phyllanthus amarus plants in dry and ash powders were used as bio-sorbents to remove Lead from the polluted water.

- To calculate the $\mathrm{pH}$ verses percentage of removal of Lead. 
- To calculate the time verses percentage of removal of Lead.

- To calculate the adsorbent doses verses percentage of removal of Lead.

- The effect of temperature verses percentage of removal of Lead

- To determine the structural analysis of bio-sorbents before and after adsorption by using FT-IR spectroscopy.

\section{EXPERIMENT}

Apparatus: Analytical balance, reagent bottles, volumetric flasks, conical flasks, pipettes, burettes, measuring jars, burette stand and Hot air oven.

Chemicals: Lead nitrate, potassium chromate, acetic acid, sodium acetate, sodium thiosulphate, hydro chloric acid $(\mathrm{HCl})$ and starch powder.

\subsection{Preparation of biosorbents powder}

The leaves, stems, fruits, seeds and flowers cut from Achyranthus aspera and Phyllanthus amarus plants were washed with distilled water and dried in sun light. The dried materials were crushed and meshed to reduce the size of the particles below $75 \mu$ and activated at $100^{\circ} \mathrm{C}$ using oven. Ash adsorbents were prepared by burning the plant materials as discussed above.

\subsection{Preparation of solutions}

1.0 gram of Lead nitrate is dissolved $1000 \mathrm{~mL}$ of distilled water to make the concentration of $1000 \mathrm{ppm}$.

\subsubsection{Preparation of Potassium chromate solution}

1.0 gram of Potassium chromate is dissolved in $1000 \mathrm{~mL}$ of water to get the concentration of $1000 \mathrm{ppm}$.

\subsubsection{Preparation of acidic buffer:}

$50 \mathrm{~mL}$ of Acidic acid is dissolved $70 \mathrm{~mL}$ of water contains 4 grams of sodium acetate.

\subsubsection{Preparation of hypo solution:}

15 grams of Sodium thio sulphate (hypo) is dissolved in $1000 \mathrm{~mL}$ of distilled water.

\subsubsection{Preparation of starch solution}

1.0 gram of starch powder is dissolved in 2 to $3 \mathrm{~mL}$ of distilled water and poured this content into $100 \mathrm{~mL}$ boiling water. Stirred the contents with glass rod and made into a uniform solution and cool to room temperature.

\subsubsection{Preparation of stock solution}

$500 \mathrm{~mL}$ reagent bottles were thoroughly washed and rinsed with distilled water and each bottle is filled with $250 \mathrm{~mL}$ of $1000 \mathrm{ppm}$ Lead nitrate solution. In reagent bottles different doses of bio-sorbents (dry and ash powders) are added and shaken well with frequent times and kept it for better adsorption of Lead. The contents are thoroughly shaken and filtered through Wattmann filter paper through funnel into a cleaned reagent bottle. The filtrate is stored in cold and dry place for further experiment. The powders of bio-sorbents before and after absorption were examined with FT-IR spectrophotometer to determine the change of the spectra due to absorption of Lead. 


\subsection{Procedure}

$20 \mathrm{~mL}$ biosorbent solution is of is pipetted out into a clean conical flask. To this same quantity of potassium chromate solution is added yellow color precipitate is formed. The precipitate is dissolved with concentrated $\mathrm{HCl}$ and $2 \mathrm{~mL}$ of acidic buffer is added. To this one gram of potassium iodide is added and closed the conical flask and kept in dark place for 5 minutes. After 5 minutes the contents are titrated against hypo until pale yellow color is reached. To this $1 \mathrm{mLof}$ starch indicator is added and titrated against hypo solution till the contents in the flask turns to pale green color. The end point is noted from the burette reading. The same procedure is repeated with blank and as well as with stock solutions of various bio sorbents.

\section{RESULTS AND DISCUSSIONS}

The removal of Lead from polluted water was investigated by changing the various physicochemical parameters like $\mathrm{pH}$, time, adsorbent doses and temperature.

\subsection{Effect of pH on adsorption of Lead}

The adsorption of Lead is observed with dry leaves, leaves ash, dry stems, stems ash, dry roots and roots ash for both the plants. A. aspera has flowers therefore flowers dry and ash powders are also taken. Both the plants are shown maximum adsorption of Lead at pH 6 and falls gradually from 6 to $10.5 \mathrm{pH}$. Among these two plants P. amarus dry fruits and fruit ash powders were shown maximum adsorption at $\mathrm{pH}$ 6. The highest adsorption of Lead was shown by P. amarus plant fruit ash, dry fruits and root ash of $88.54 \%, 86.75 \%$ and $84.70 \%$ respectively. A. aspera flower ash has highest $84.69 \%$ of adsorption where as dry flowers have $80.61 \%$ of adsorption and stem ash have $76.66 \%$ adsorption of Lead. The least adsorption was shown by dry leaves of $\mathrm{A}$. aspera dry leaves $11.02 \%$ and $\mathrm{P}$. amarus dry roots $12 \%$ at $10.5 \%$. The percentage of removal of Lead by biosorbents powders of two plants were presented in theTable-1. The adsorption isotherms were shown in the Graph-1 and 2.

Table 1 Effect of $\mathrm{pH}$ on \% of removal of Lead by Achyranthus aspera and Phyllanthus amarus

\begin{tabular}{|c|c|c|c|c|c|c|c|c|c|c|}
\hline pH & $\begin{array}{c}\text { dry } \\
\text { leaves }\end{array}$ & $\begin{array}{c}\text { leave } \\
\text { ash }\end{array}$ & $\begin{array}{c}\text { dry } \\
\text { stems }\end{array}$ & $\begin{array}{c}\text { stem } \\
\text { ash }\end{array}$ & $\begin{array}{c}\text { Dry } \\
\text { roots }\end{array}$ & $\begin{array}{c}\text { Root } \\
\text { ash }\end{array}$ & $\begin{array}{c}\text { Dry } \\
\text { Flower }\end{array}$ & $\begin{array}{c}\text { Flower } \\
\text { ash }\end{array}$ & $\begin{array}{c}\text { Dry } \\
\text { seed }\end{array}$ & Seed ash \\
\hline 4 & 21.20 & 29.96 & 20.65 & 27.62 & 28.01 & 26.45 & 46.15 & 52.89 & 37.36 & 38.25 \\
& 22.29 & 26.09 & 20.61 & 25.32 & 25.29 & 30.73 & & & 34.17 & 39.45 \\
\hline 6 & 70.17 & 73.68 & 75.43 & 76.66 & 50.8 & 71.92 & 80.61 & 84.69 & 67.2 & 69.38 \\
& 63.58 & 70.31 & 65.27 & 73.25 & 75.43 & 84.70 & & & 86.75 & 88.54 \\
\hline 8 & 29.45 & 41.97 & 41.65 & 44.32 & 35.42 & 45.92 & 47.23 & 48.98 & 32 & 35.85 \\
& 47.36 & 50.97 & 40.65 & 44 & 46.62 & 49.32 & & & 52.69 & 56.37 \\
\hline 10.5 & 11.02 & 15.24 & 16.81 & 20.09 & 25.20 & 15.40 & 64.52 & 68.35 & 60.28 & 62.93 \\
& 15.13 & 18.54 & 16.0 & 20.13 & 12 & 18.36 & & & 20.15 & 25.14 \\
\hline
\end{tabular}




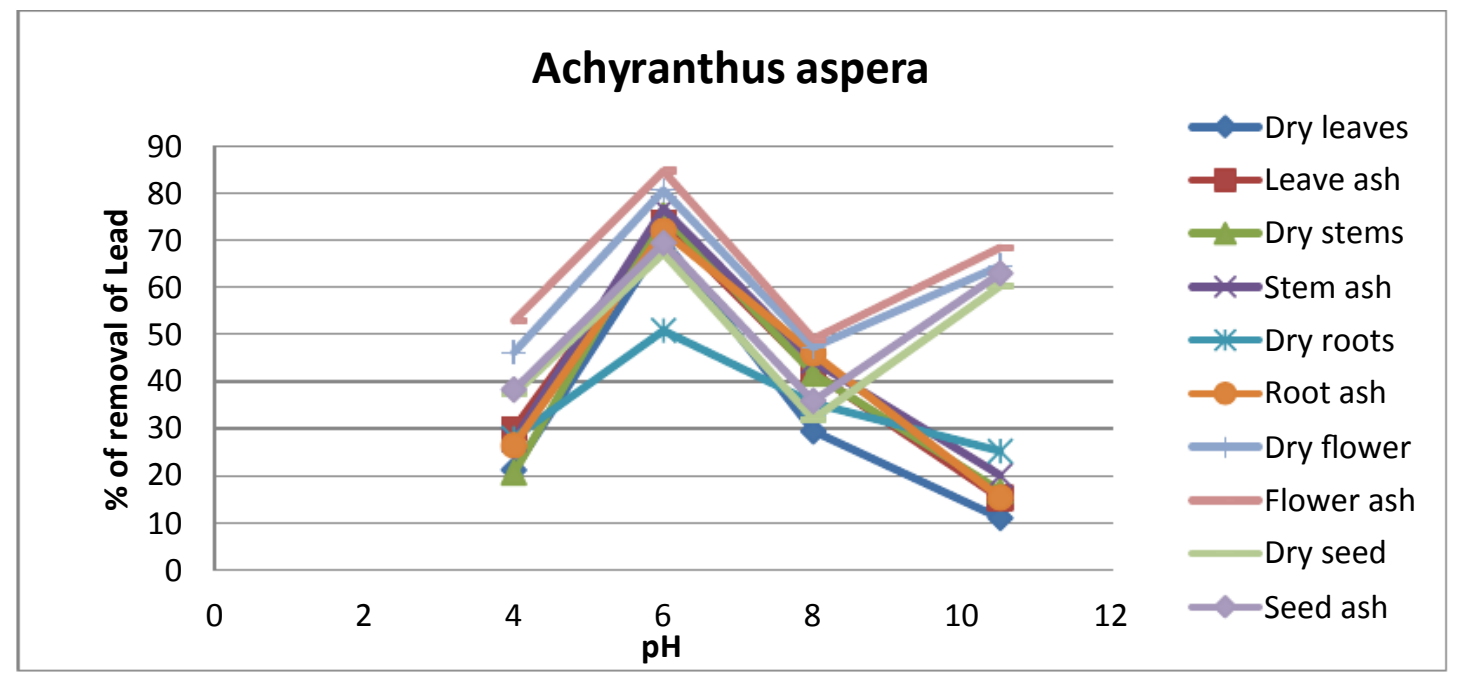

Graph-1 Effect of $\mathrm{pH}$ on \% of removal of Lead by Achyranthus aspera

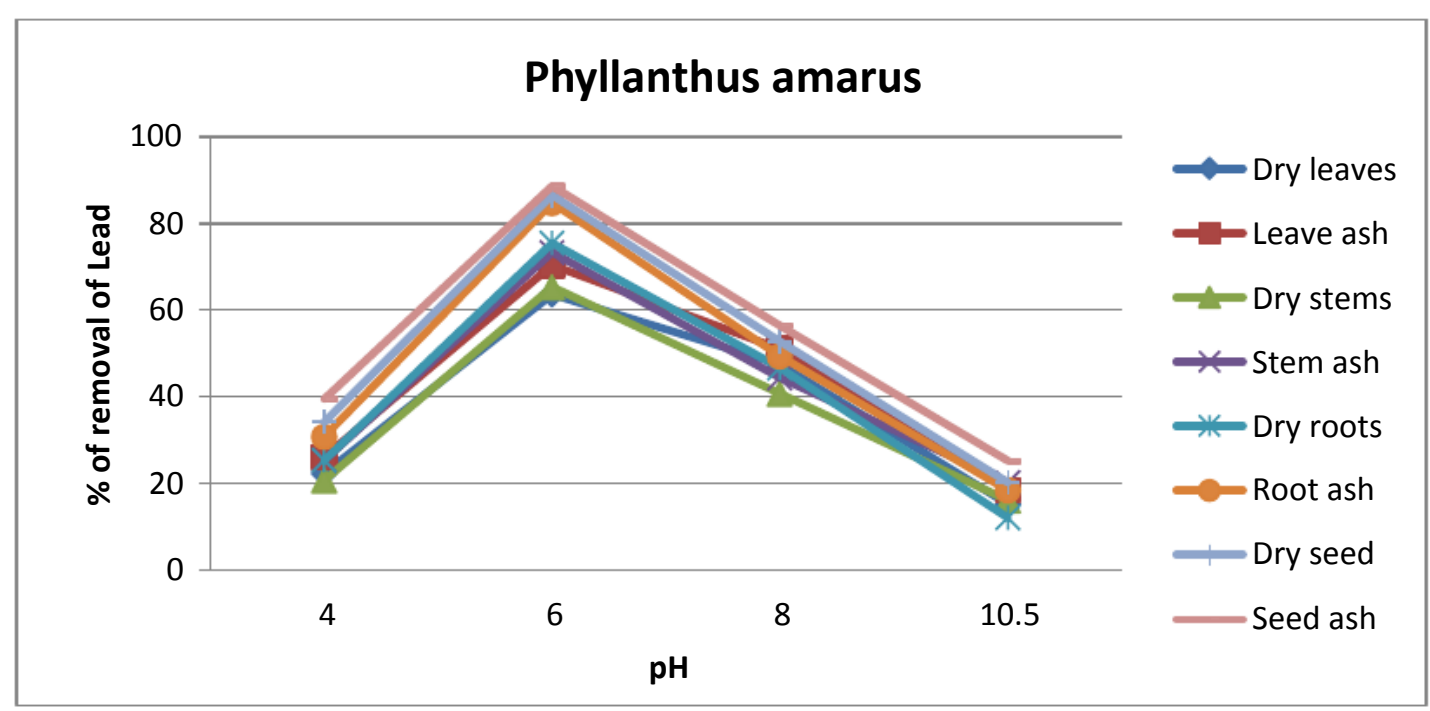

Graph-2 Effect of $\mathrm{pH}$ on \% of removal of Lead by Phyllanthus amarus

\subsection{Effect of time on adsorption of Lead}

By increasing the time from 1 to 7 days by frequent shaking, flower ash of A. asper has shown highest $86.53 \%$ adsorption on $5^{\text {th }}$ day and $84.69 \%$ on $7^{\text {th }}$ day. Followed by dry flowers have shown $81.54 \%$ on $5^{\text {th }}$ day and $80.61 \%$ on $7^{\text {th }}$ day of adsorption of Lead. It has been observed that by increasing the time from 1to 5 days with different bio-sorbents, the removal of Lead has increased gradually from dry roots to seed ash. P.amarus has shown maximum adsorption of Lead in $7^{\text {th }}$ day. The maximum absorption of Lead was shown by fruit ash $88.54 \%$ and dry fruits $86.75 \%$. The least adsorption was shown by dry roots $50.8 \%$ of $\mathrm{A}$. aspera and dry leaves $62.31 \%$ of $\mathrm{P}$. amarus. The \% of removal of Lead by bio sorbent powders of two plants were shown in theTable-2. The absorption isotherms are shown in the Graph-3 and 4.

Table 2 Effect of Time on \% of removal of Lead by Achyranthus aspera and Phyllanthus amarus

\begin{tabular}{|c|c|c|c|c|c|c|c|c|c|c|}
\hline $\begin{array}{c}\text { Time } \\
\text { in days }\end{array}$ & $\begin{array}{c}\text { dry } \\
\text { leaves }\end{array}$ & $\begin{array}{c}\text { leaves } \\
\text { ash }\end{array}$ & $\begin{array}{c}\text { dry } \\
\text { stems }\end{array}$ & $\begin{array}{c}\text { stems } \\
\text { ash }\end{array}$ & $\begin{array}{c}\text { dry } \\
\text { roots }\end{array}$ & $\begin{array}{c}\text { Root } \\
\text { ash }\end{array}$ & $\begin{array}{c}\text { Dry } \\
\text { Flower }\end{array}$ & $\begin{array}{c}\text { Flower } \\
\text { ash }\end{array}$ & $\begin{array}{c}\text { Dry } \\
\text { seeds }\end{array}$ & Seed ash \\
\hline 1 & 22.01 & 25.64 & 28.29 & 36.48 & 26.57 & 29.68 & 42.15 & 46.78 & 42.0 & 41.53 \\
& 14.01 & 15.25 & 17.21 & 18.72 & 14.57 & 16.56 & & & 17.59 & 21.25 \\
\hline
\end{tabular}


Comparative Study of Achyranthus Aspera and Phyllanthus Amarus for the Removal of Lead from Polluted Water by using their Biosorbents Powder

\begin{tabular}{|c|c|c|c|c|c|c|c|c|c|c|}
\hline 3 & 32.34 & 36.45 & 39.54 & 41.25 & 45.89 & 49.01 & 52.65 & 59.63 & 54.97 & 54.29 \\
& 32.58 & 35.94 & 34.25 & 39.89 & 35.82 & 39.01 & & & 41.59 & 45.66 \\
\hline 5 & 45.52 & 51.25 & 46.25 & 54.05 & 61.97 & 72.63 & 81.54 & 86.53 & 73.51 & 72.69 \\
& 40.57 & 43.25 & 42.18 & 44.05 & 41.97 & 43.62 & & & 50.14 & 55.39 \\
\hline 7 & 70.17 & 73.68 & 75.43 & 76.66 & 50.8 & 71.92 & 80.61 & 84.69 & 70.81 & 69.38 \\
& 62.31 & 67.24 & 69.82 & 76.66 & 75.43 & 84.70 & & & 86.75 & 88.54 \\
\hline
\end{tabular}

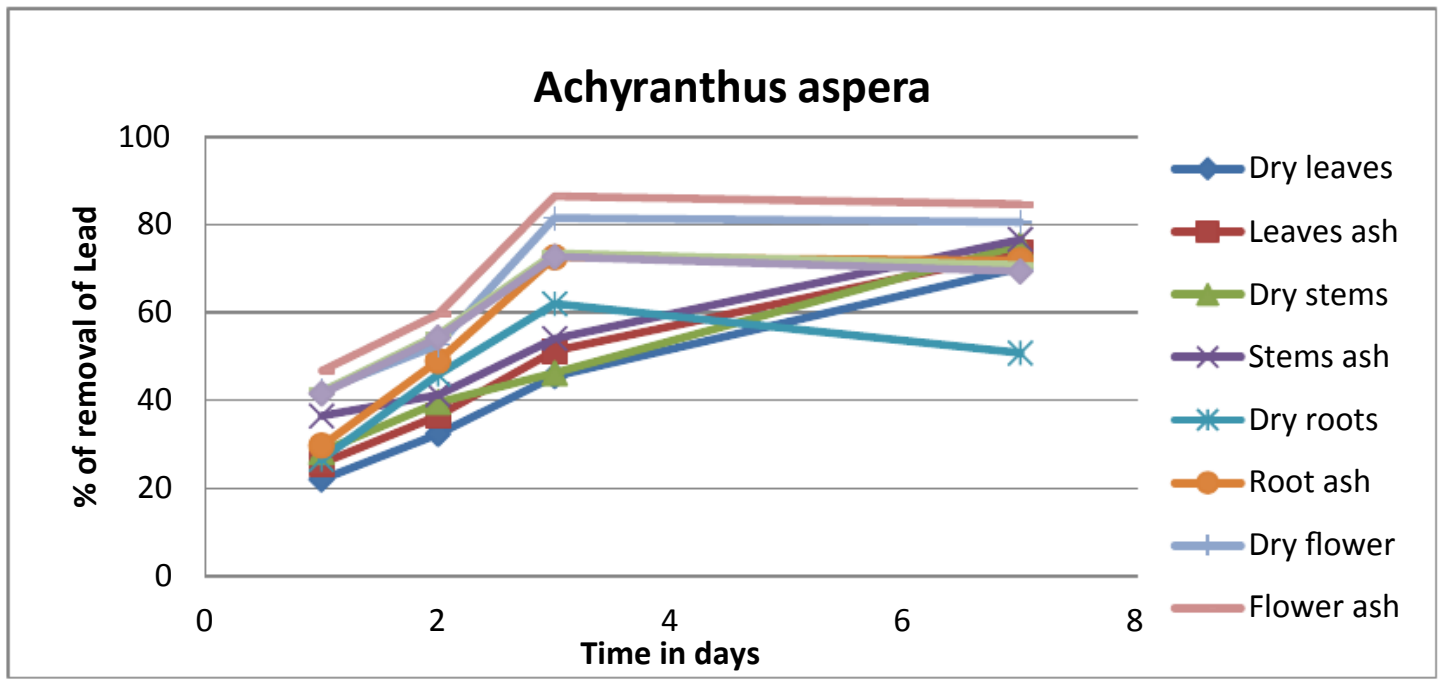

. Graph-3 Effect of Time on \% of removal of Lead by Achyranthus aspera

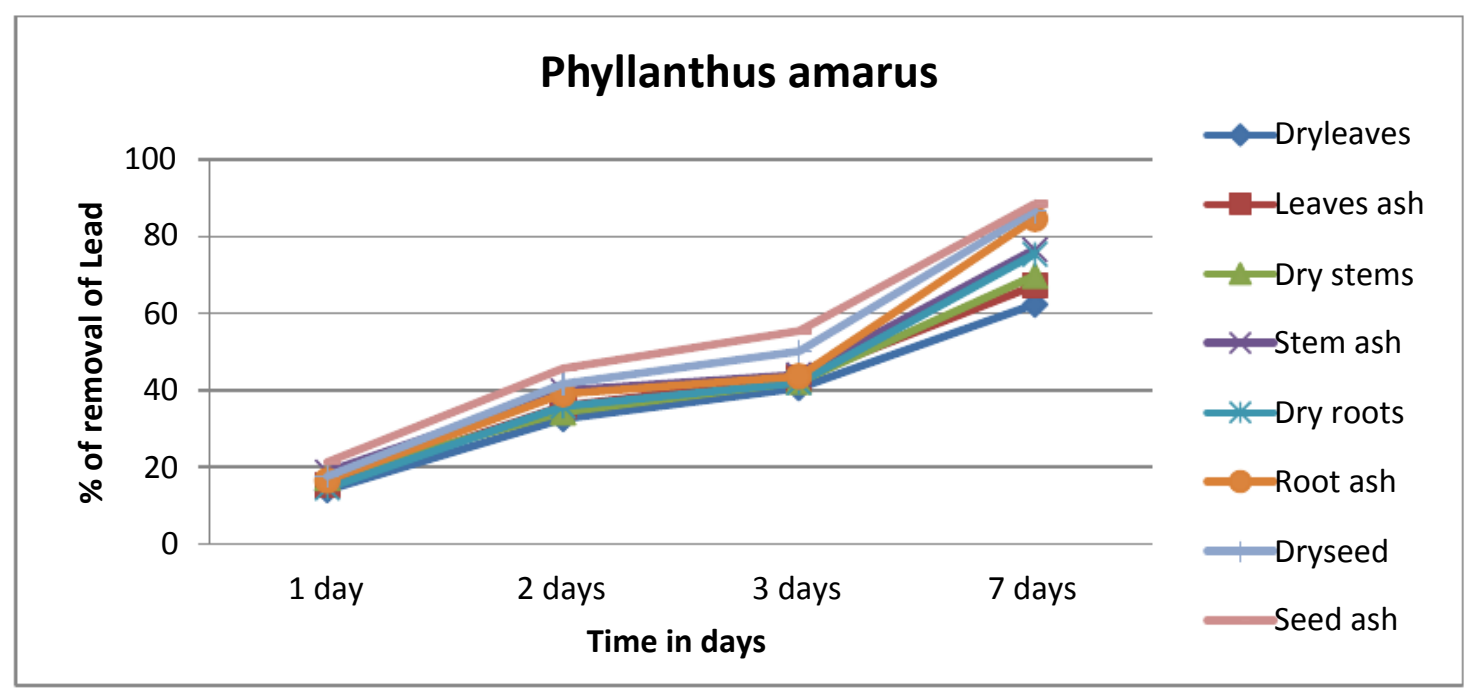

Graph-4 Effect of Time on \% of removal of Lead by Phyllanthus amarus

\subsection{Effect of adsorbent doses on adsorption of Lead}

The doses of adsorbent powders were increasing from $0.25 \mathrm{gm}$ to $1 \mathrm{gm}$, the elimination of Lead has also increased gradually. A. aspera flowers ash has maximum adsorption of $84.69 \%$ and $81.65 \%$ at $1 \mathrm{~g}$ and $0.75 \mathrm{~g}$ doses. At $1 \mathrm{~g}$ of adsorbent dose P.amarus fruit ashes $88.54 \%$ and dry fruits $86.75 \%$ has shown highest adsorption of Lead. Dry leaves of P.amarus have shown $14.01 \%$ of least adsorption at $0.25 \mathrm{~g}$ doses of biosorbent powder. The $\%$ of removal of Lead by bio sorbent powders of two plants were presented in theTable-3. The adsorption isotherms are shown in the graph-5 and 6. 
K. Jaya Prasanthi and A. Aruna Kumari

Table 3 Effect of absorbent doses on \% of removal of Lead by Achyranthus aspera and Phyllanthus amarus

\begin{tabular}{|c|c|c|c|c|c|c|c|c|c|c|}
\hline $\begin{array}{c}\text { Absorbent } \\
\text { doses }\end{array}$ & $\begin{array}{c}\text { dry } \\
\text { leaves }\end{array}$ & $\begin{array}{c}\text { leaves } \\
\text { ash }\end{array}$ & $\begin{array}{c}\text { dry } \\
\text { stem }\end{array}$ & $\begin{array}{c}\text { stem } \\
\text { ash }\end{array}$ & $\begin{array}{c}\text { dry } \\
\text { roots }\end{array}$ & $\begin{array}{c}\text { Root } \\
\text { ash }\end{array}$ & $\begin{array}{c}\text { Dry } \\
\text { Flower }\end{array}$ & $\begin{array}{c}\text { Flower } \\
\text { ash }\end{array}$ & $\begin{array}{c}\text { Dry } \\
\text { seed }\end{array}$ & Seed ash \\
\hline 0.25 & 34.01 & 39.64 & 45.23 & 48.65 & 52.16 & 56.56 & 60.25 & 64.53 & 61.09 & 59.65 \\
& 14.01 & 16.34 & 15.21 & 17.73 & 14.57 & 16.56 & & & 20.54 & 28.59 \\
\hline 0.5 & 45.26 & 49.65 & 56.28 & 61.27 & 68.53 & 70.25 & 74.28 & 79.86 & 71.99 & 71.56 \\
& 28.24 & 36.89 & 41.69 & 44.07 & 43.99 & 45.62 & & & 56.27 & 60.58 \\
\hline 0.75 & 58.36 & 65.34 & 69.81 & 70.76 & 71.32 & 72.08 & 76.85 & 81.65 & 68.21 & 68.45 \\
& 50.19 & 55.97 & 60.81 & 67.76 & 70.83 & 71.14 & & & 77.58 & 80.15 \\
\hline 1 & 70.17 & 73.68 & 73.68 & 44.07 & 50.8 & 71.92 & 80.61 & 84.69 & 71.0 & 69.38 \\
& 62.31 & 67.24 & 69.82 & 76.66 & 75.43 & 84.70 & & & 86.75 & 88.54 \\
\hline
\end{tabular}

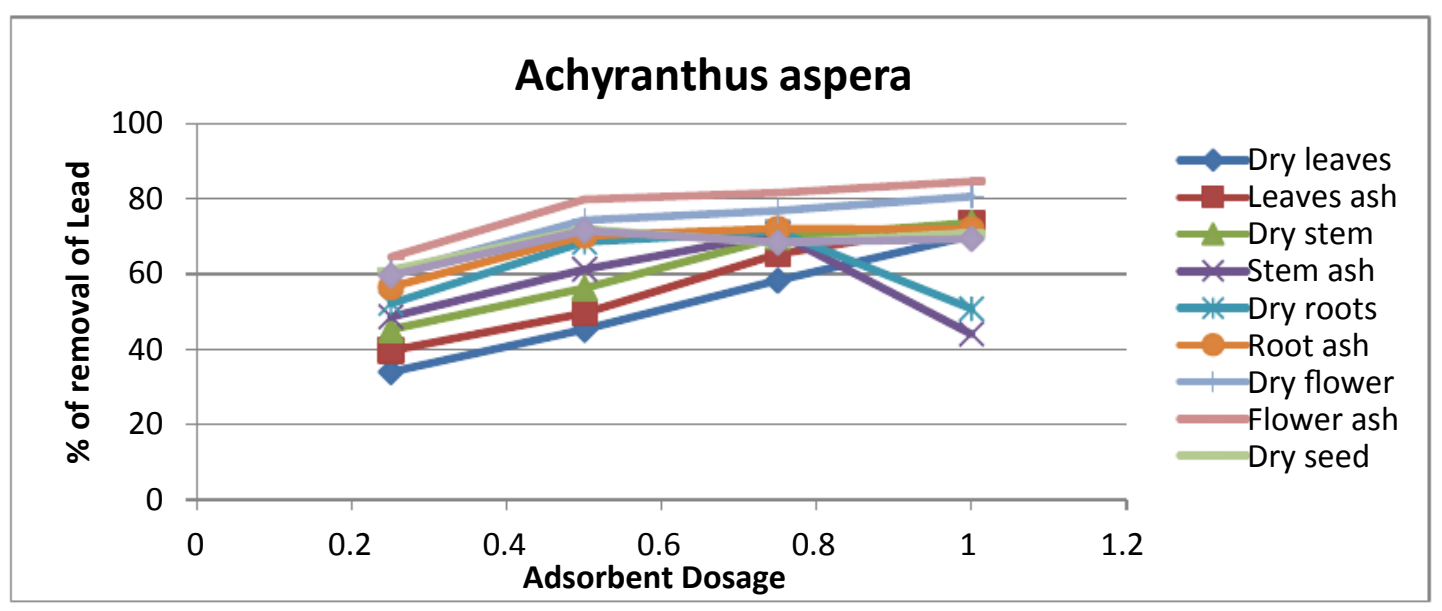

Graph-5 Effect of Doses on \% of removal of Lead by Achyranthus aspera

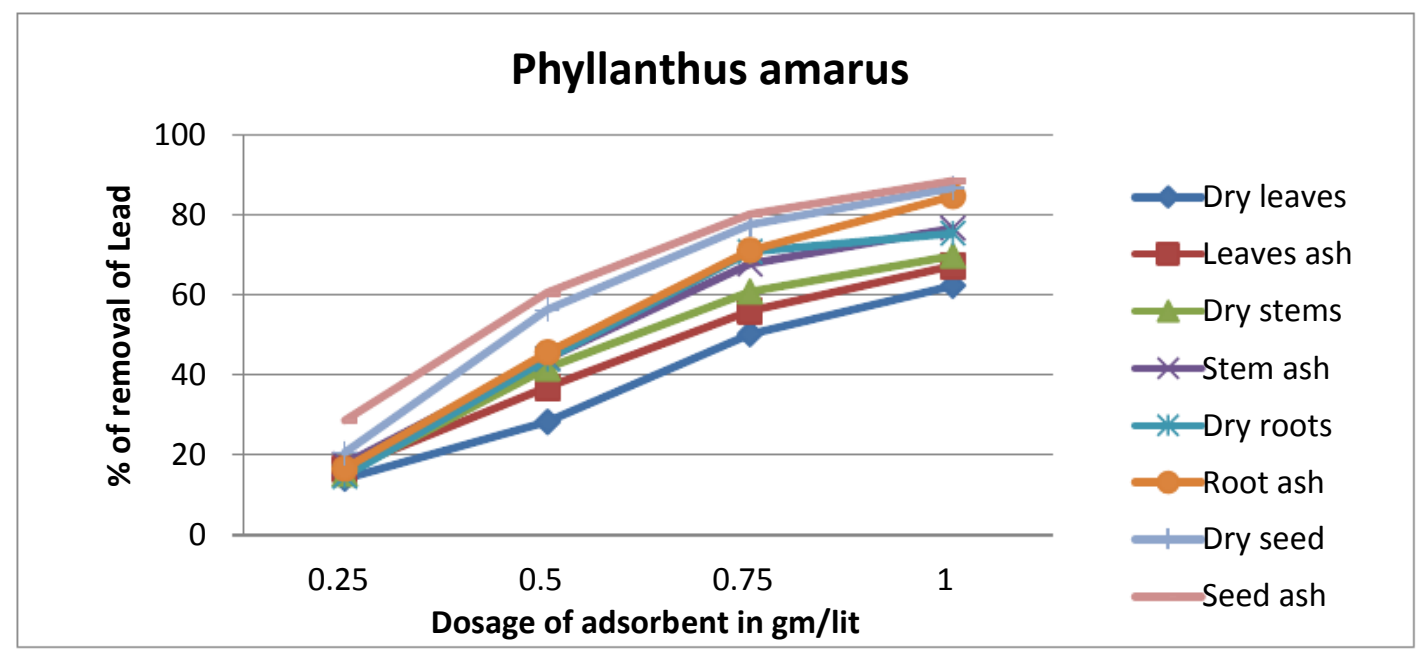

Graph-6 Effect of Doses on \% of removal of Lead by Phyllanthus amarus

\subsection{Effect of temperature on the adsorption of Lead}

At $293 \mathrm{~K}$, adsorption of Lead was high by all adsorbents of two plants. P.amarus fruits ash has shown maximum adsorption of $88.54 \%$ followed by dry fruits $86.75 \%$ and root ash $84.69 \%$ of adsorption. A.aspera flower ash has shown highest adsorption among its adsorbent powders. Temperature of bio-sorbents solution increased by heating the solutions, it is observed that adsorption rate is decreased with increase in the temperature upto $313 \mathrm{~K}$. Least adsorption was 
Comparative Study of Achyranthus Aspera and Phyllanthus Amarus for the Removal of Lead from Polluted Water by using their Biosorbents Powder

shown by P.amarus dry leaves $14.51 \%$ among the two plants at $313 \mathrm{~K}$ temperature. The $\%$ of removal of Lead by biosorbent powders were presented in theTable-4.The absorption isotherms are shown in the Graph-7 and 8.

Table 4 Effect of temperature on \% of removal of Lead by Achyranthus aspera and Phyllanthus amarus

\begin{tabular}{|l|c|c|c|c|c|c|c|c|c|c|}
\hline Temp. & $\begin{array}{c}\text { dry } \\
\text { leaves }\end{array}$ & $\begin{array}{c}\text { leaves } \\
\text { ash }\end{array}$ & $\begin{array}{c}\text { dry } \\
\text { stems }\end{array}$ & $\begin{array}{c}\text { stems } \\
\text { ash }\end{array}$ & $\begin{array}{c}\text { dry } \\
\text { roots }\end{array}$ & $\begin{array}{c}\text { Root } \\
\text { ash }\end{array}$ & $\begin{array}{c}\text { dry } \\
\text { flower }\end{array}$ & $\begin{array}{c}\text { flower } \\
\text { ash }\end{array}$ & $\begin{array}{c}\text { Dry } \\
\text { seed }\end{array}$ & $\begin{array}{c}\text { Seed } \\
\text { ash }\end{array}$ \\
\hline $293 \mathrm{~K}$ & 70.17 & 73.68 & 73.68 & 76.66 & 75.43 & 75.18 & 80.61 & 84.69 & 70.11 & 69.38 \\
& 62.31 & 67.24 & 69.82 & 72.81 & 74.61 & 84.70 & & & 86.75 & 88.54 \\
\hline $303 \mathrm{~K}$ & 41.32 & 44.35 & 42.35 & 48.09 & 46.62 & 48.81 & 49.0 & 51.73 & 45.72 & 42.76 \\
& 31.32 & 35.56 & 41.99 & 46.85 & 47.87 & 49.0 & & & 51.27 & 55.26 \\
\hline $313 \mathrm{~K}$ & 18.29 & 19.25 & 19.14 & 23.25 & 21.13 & 22.56 & 23.31 & 25.17 & 21.14 & 19 \\
& 14.51 & 17.58 & 18.93 & 21.58 & 28.59 & 32.79 & & & 34.25 & 39.47 \\
\hline
\end{tabular}

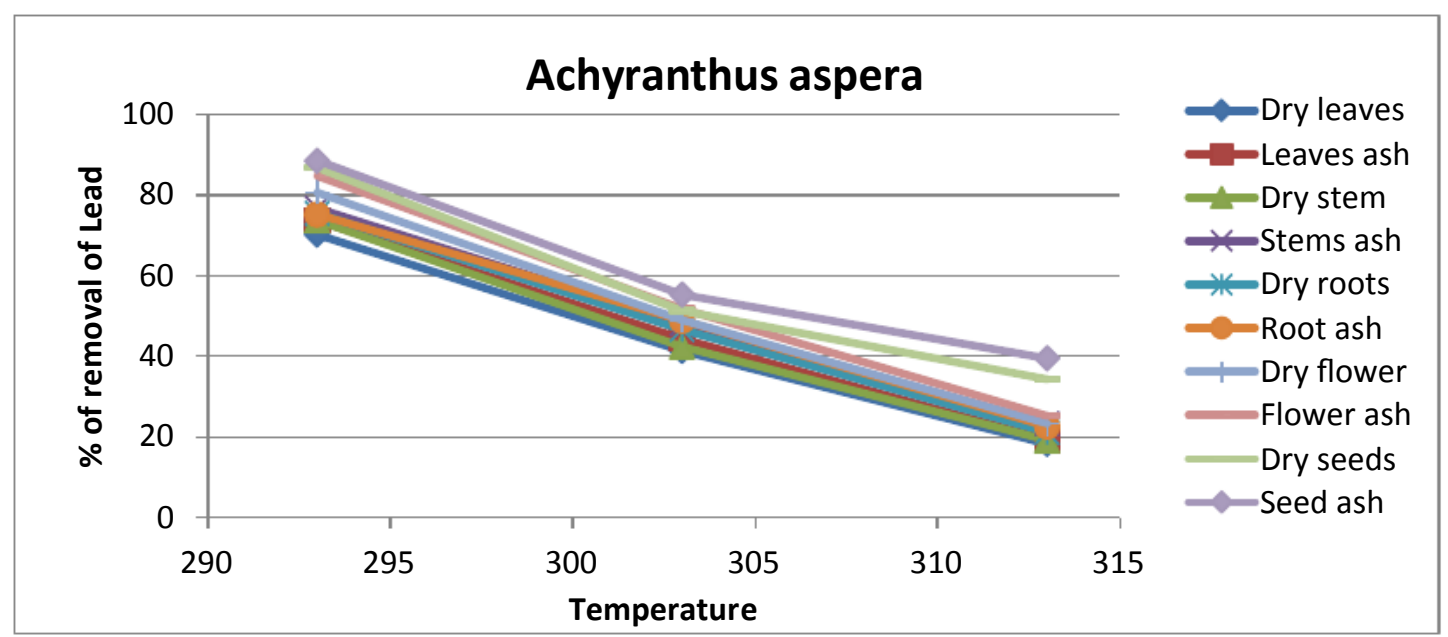

Graph-7 Effect of Temperature on \% of removal of Lead by Achyranthus aspera

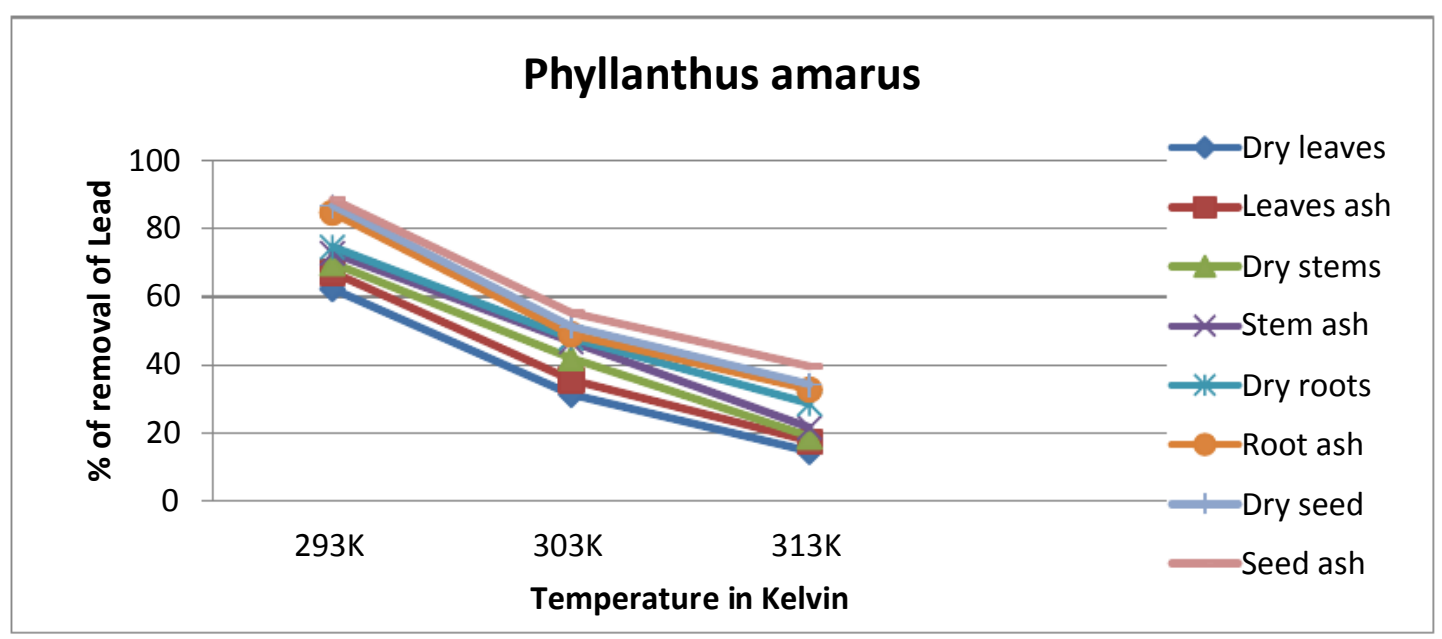

Graph-8 Effect of Temperature on \% of removal of Lead by Phyllanthus amarus 


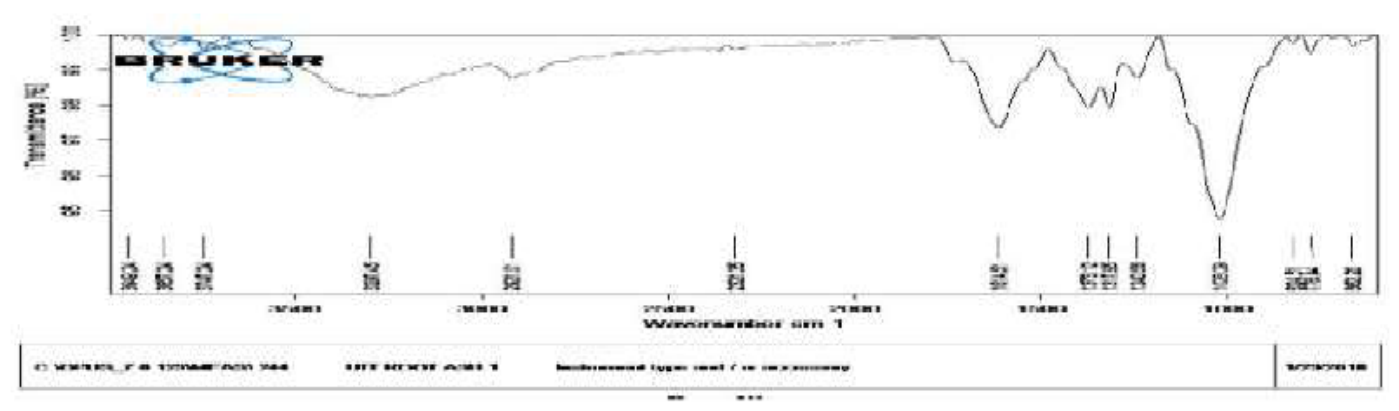

Figure 2. FT-IR spectra of Achyranthes aspera root ash before adsorption

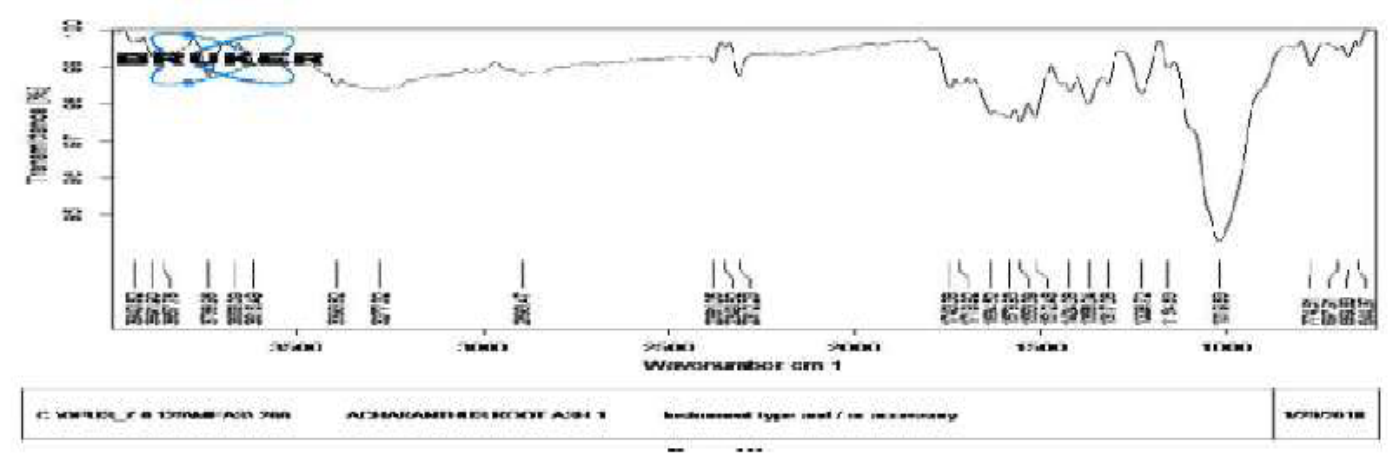

Figure 3. FT-IR spectra of Achyranthes aspera root ash after adsorption

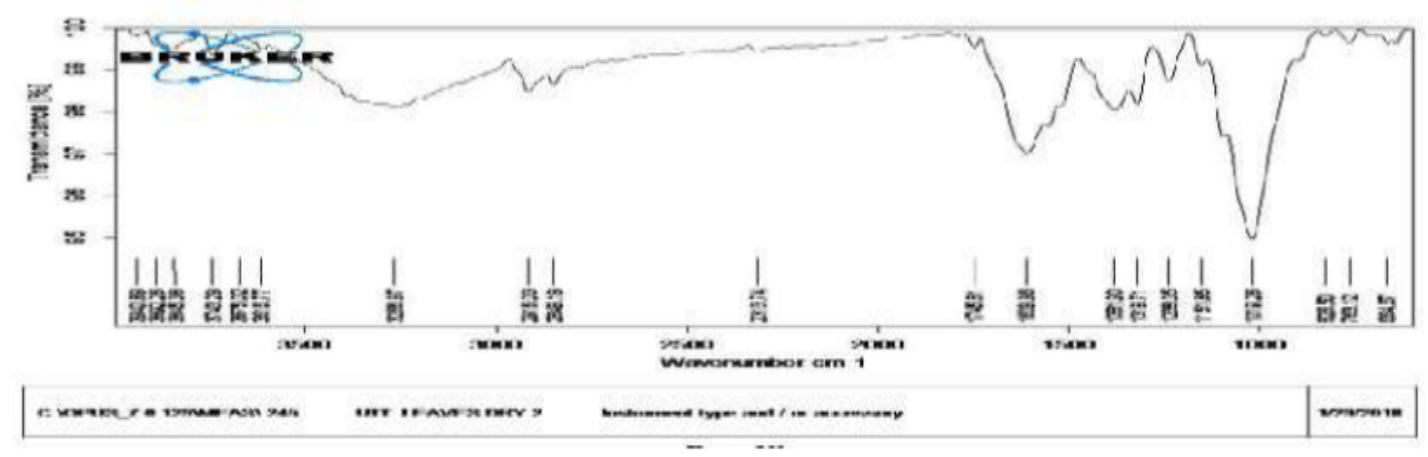

Figure 4. FT-IR spectra of Achyranthes aspera leaves dry before adsorption

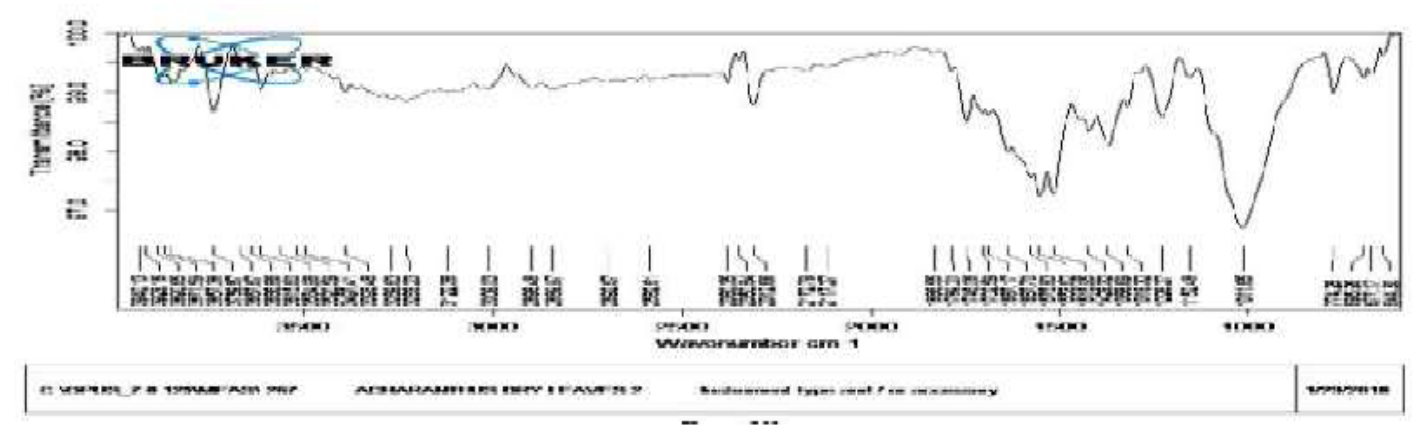

Figure 5. FT-IR spectra of Achyranthes aspera leaves dry after adsorption 
Comparative Study of Achyranthus Aspera and Phyllanthus Amarus for the Removal of Lead from Polluted Water by using their Biosorbents Powder

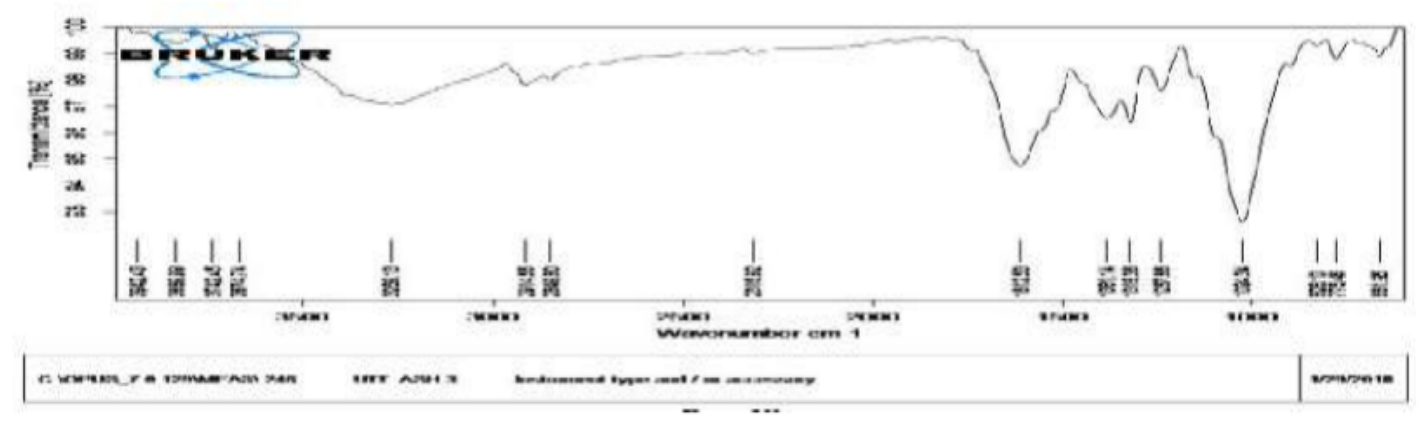

Figure 6. FT-IR spectra of Achyranthes aspera leaves ash before adsorption

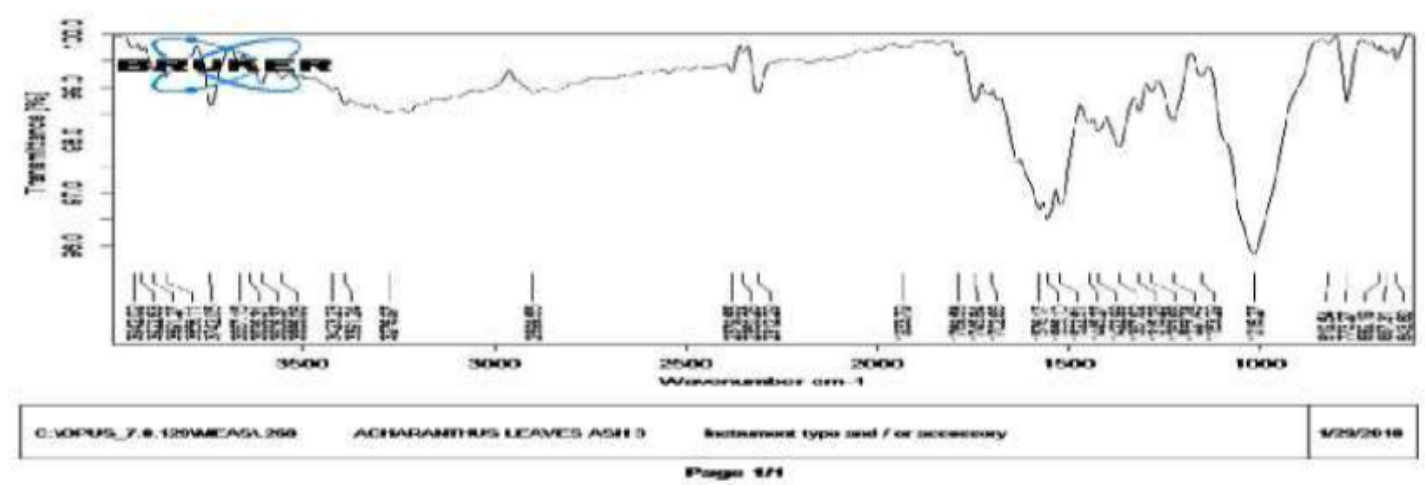

Figure 7. FT-IR spectra of Achyranthes aspera leaves ash after adsorption

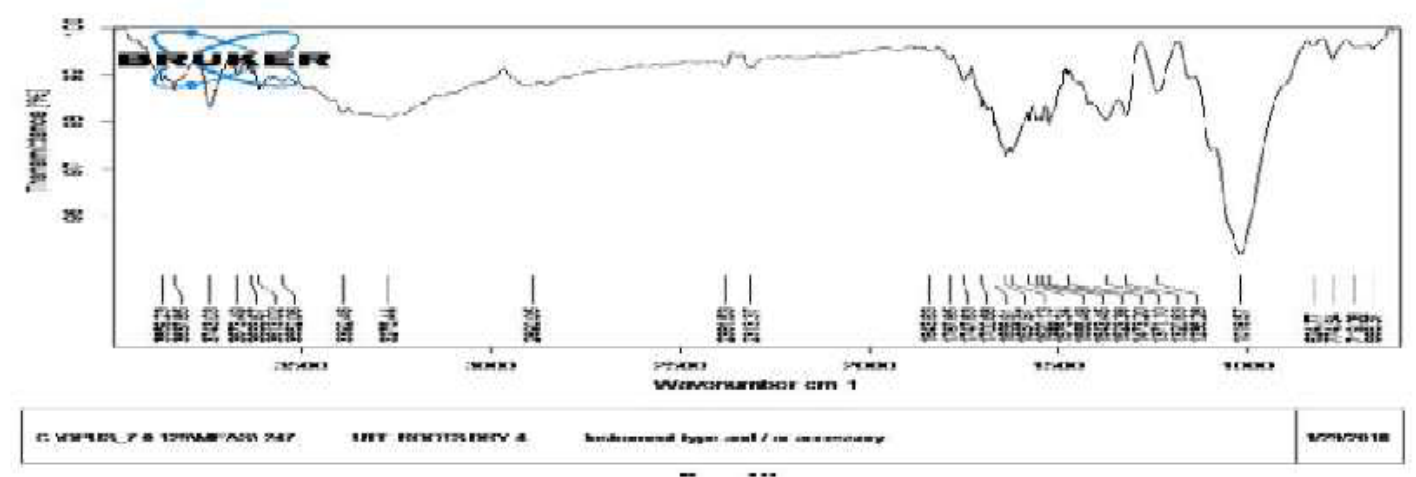

Figure 8. FT-IR spectra of Achyranthes aspera roots dry before adsorption

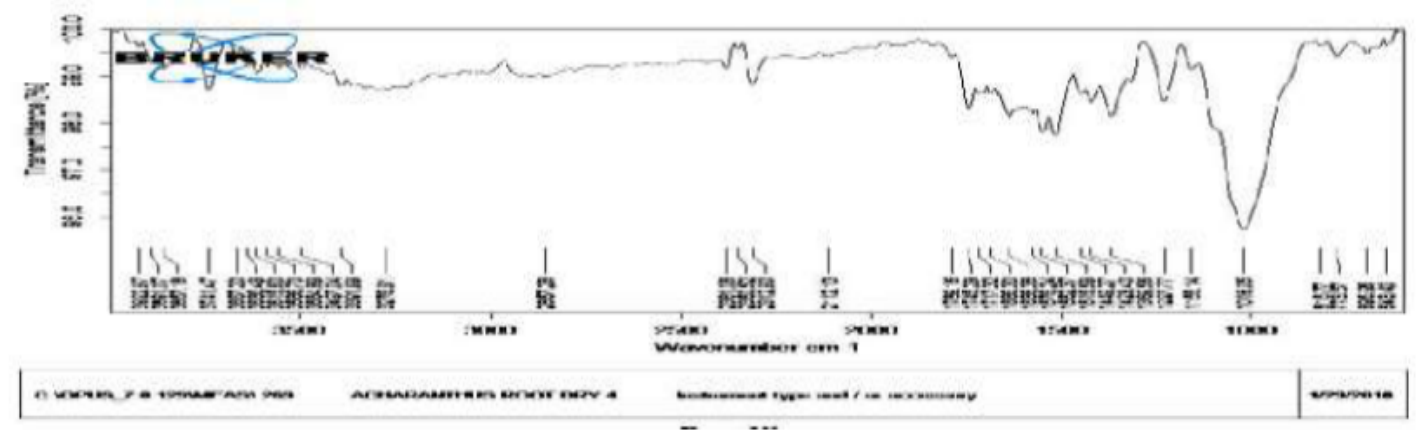

Figure 9. FT-IR spectra of Achyranthes aspera roots dry after adsorption 


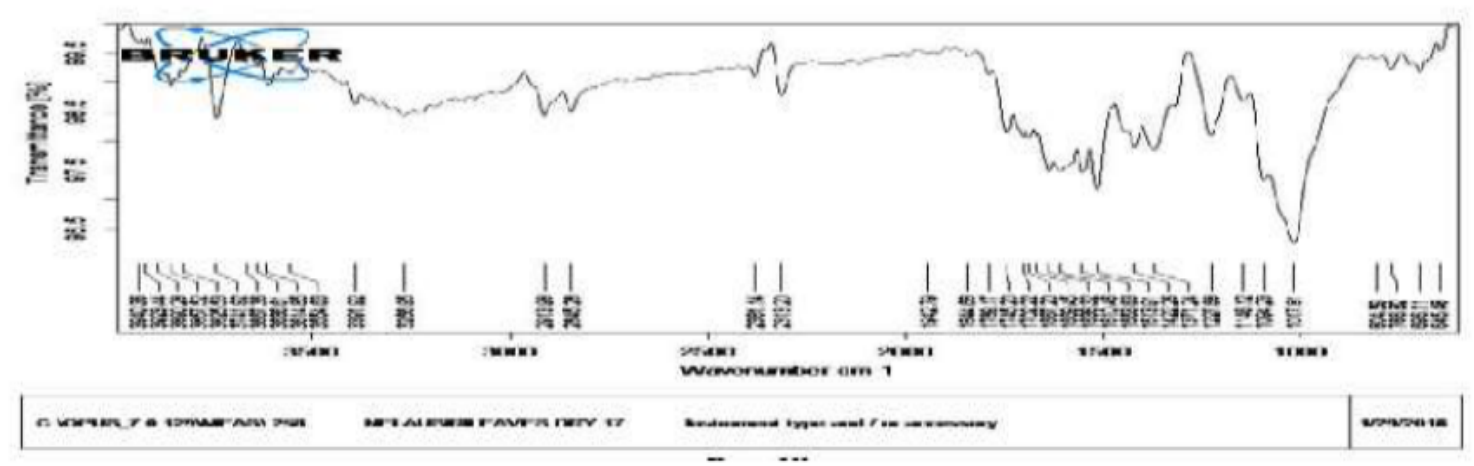

Figure 10. FT-IR spectra of Phyllanthus amarus leaves dry before adsorption

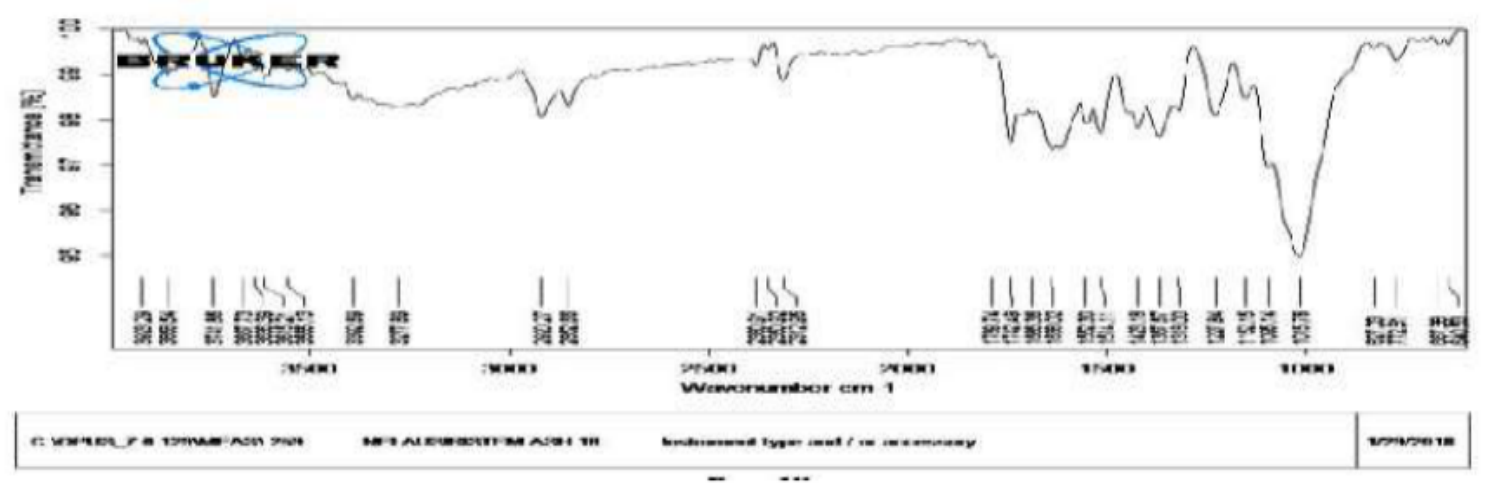

Figure 12. FT-IR spectra of Phyllanthus amarus stem ash before adsorption

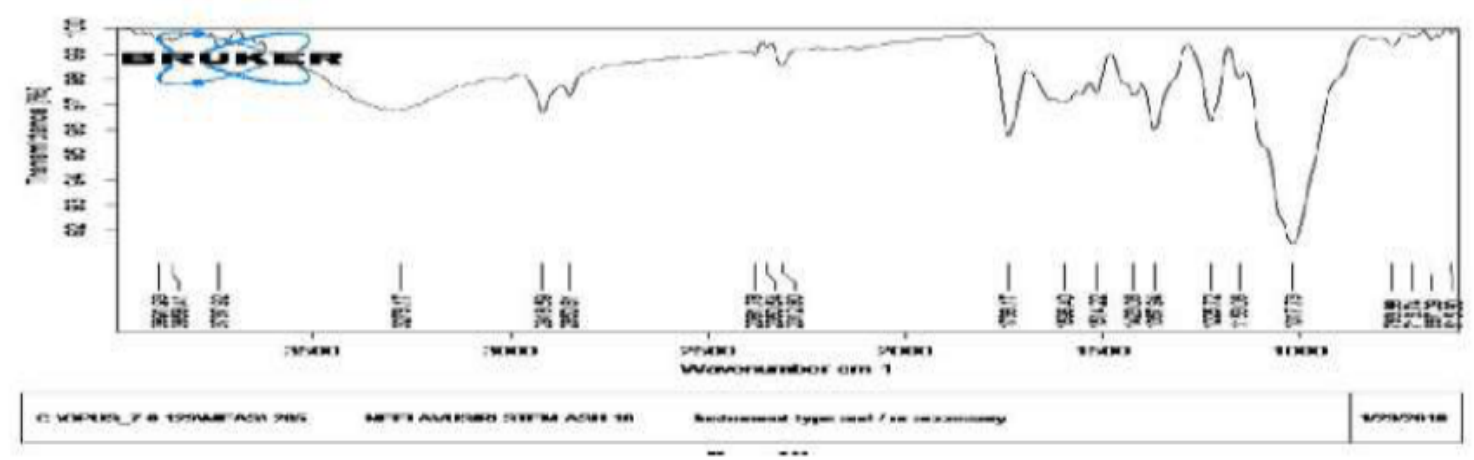

Figure 13. FT-IR spectra of Phyllanthus amarus stem ash after adsorption

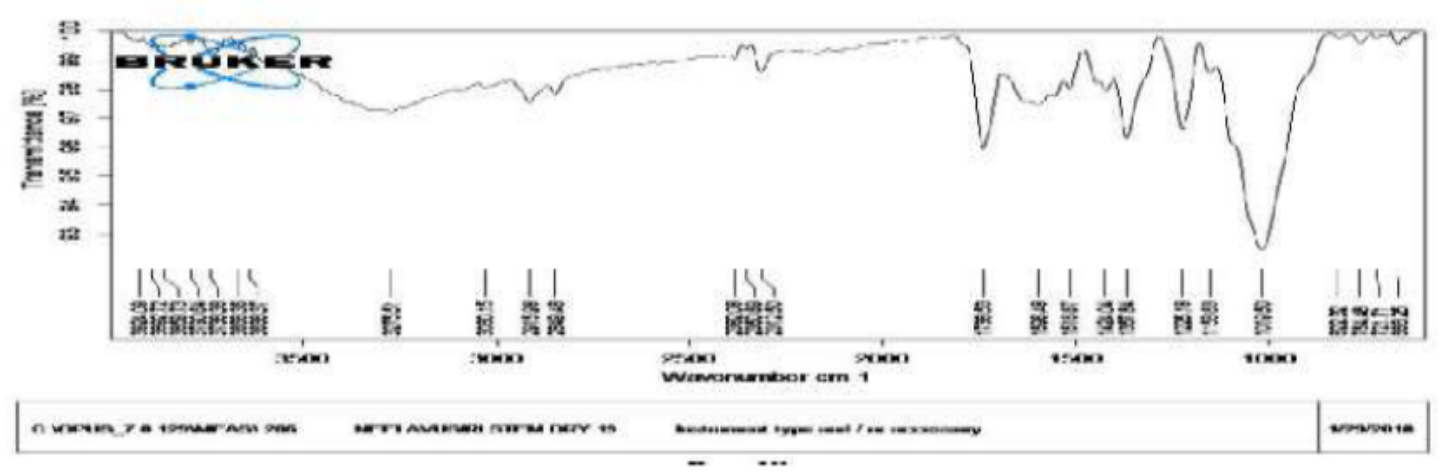

Figure 14. FT-IR spectra of Phyllanthus amarus stem dry before adsorption 


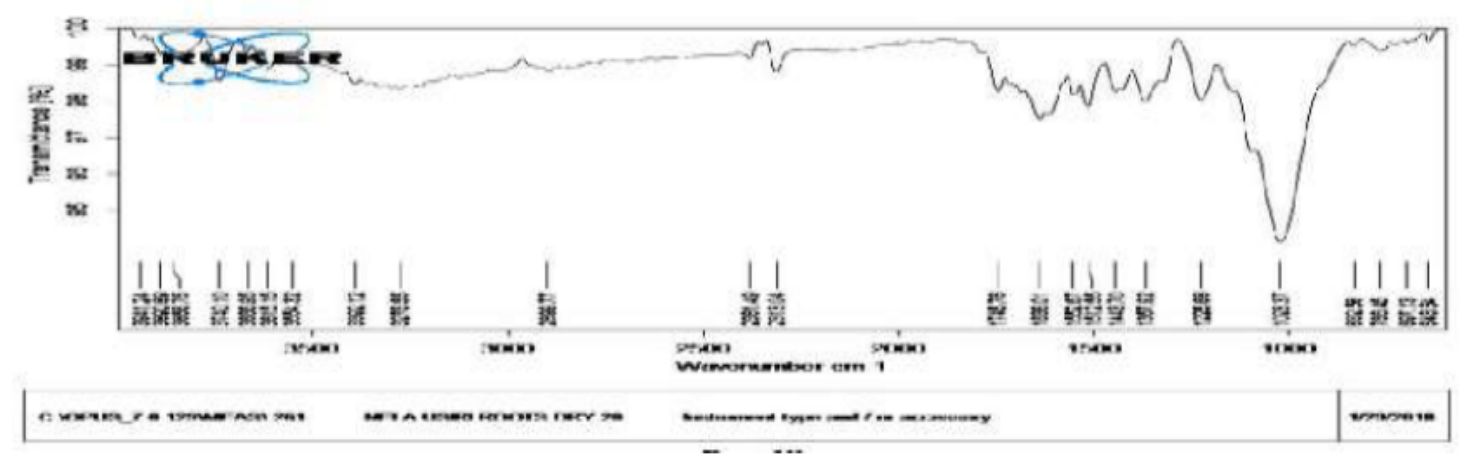

Figure 15. FT-IR spectra of Phyllanthus amarus roots dry before adsorption

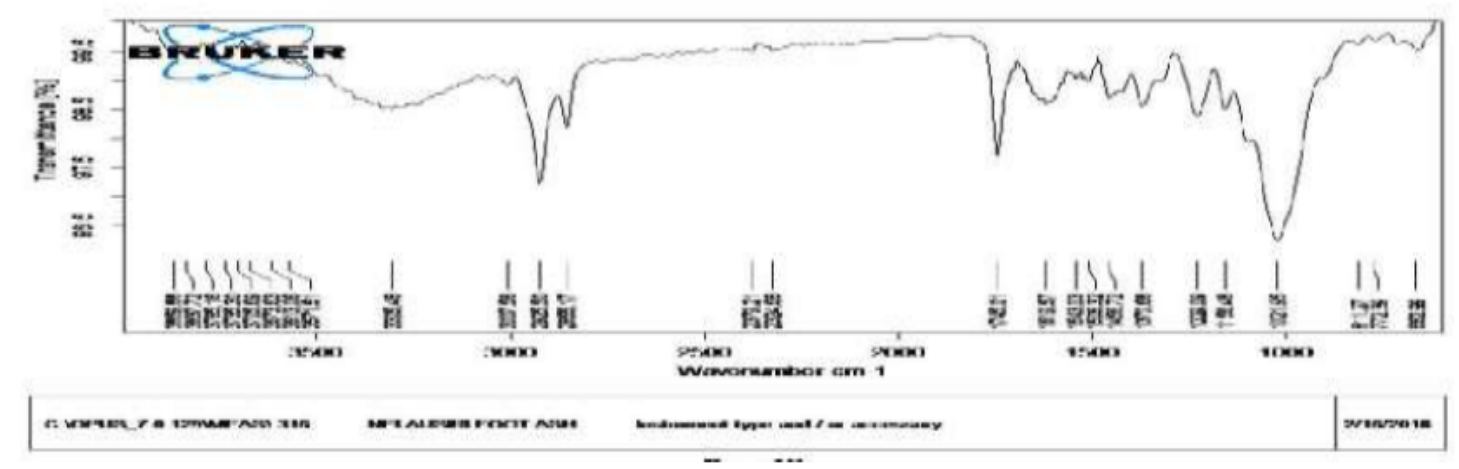

Figure 16. FT-IR spectra of Phyllanthus amarus roots ash before adsorption

\section{CONCLUSIONS}

The bio-sorbents extracted from Achyranthus aspera and Phyllanthus amarus plants were used for the removal of Lead from polluted water by developing a new and simple volumetric method. The developed method is experimented with different $\mathrm{pH}$ range, adsorbent doses, different times and Temperatures. In this we find out P.amarus plant has shown high adsorption than A. aspera plant. The percentage of removal of Lead is $88.54 \%$ with seeds ash powder of P.amarus and $84.69 \%$ with flower ash of A.aspera at $\mathrm{pH} 6$. The least adsorption of Lead 14.01 was observed by P.amarus in this experiment. The removal of Lead is high by most of the bio-sorbents powder of the two plants. The developed method is inexpensive and sustainable for the removal of Lead from polluted water which makes soil and water free Lead pollution.

\section{ACKNOWLEDGEMENTS}

One of the authors Dr. K. Jaya Prasanthi is highly thankful to UGC, SERO, Hyderabad for funding this project. The authors express gratitude towards the Management and Principal of Bapatla College of Arts \& Sciences, Bapatla for providing necessary facilities to complete this project.

\section{REFERENCES}

[1] Green wood and Earn Shah - 1998 pp 372.

[2] Green wood and Earn Shah - 1998 pp 372 to 373. 
[3] Baird and Cann - 2012 pp 537 to 538, 543 to 547.

[4] Parker- 2005 pp 194 to 195.

[5] Krestovhikoff and Hals - 2006 pp 70.

[6] Pink Lead Research - Weathering to parapets.

[7] Putnam - 2003 pp 216.

[8] National Council on Radiation, Protection and Measurements - 2004 pp 16.

[9] Rudolph Etal - 2003 pp 369.

[10] Kosnett - 2006 pp 238.

[11] Chandrakanth D. Shendkar, Rasika C. Torane, Sangita M. Lavate RAMA, K. Bhadekar, Nirmala R. Deshpande. Efficient adsorption of $\mathrm{Pb}^{+2}$ and $\mathrm{Cd}^{+2}$ from effluents on eco-friendly and low cost

[12] Adsorbent developed from Achyranthes aspera Linn. Stem. Bio med RX 2013, 1(2) 149-153.

[13] Marques P. Rosa MF, Pin Heiro HM, pH effects on the removal of $\mathrm{Cu}^{+2}, \mathrm{Cd}^{+2}$ and $\mathrm{Pb}^{+2}$ from aquous solution by waste brewery waste, Bio Processess eng. 2000, 23, 135-141.

[14] Genevieve Etornam Adukpo, John Prosper Kwaka Adoty, Daniel Gyingiry Achel, Shioh DEDE OSAF, Joseph Richmond, FIANKO, Bright Adu-Gyamfi and Demins OwsavsAMANKWAA. Trace and heavy metals analysis of Phyllanthus amarus and Phyllanthus fraternus in Ghana. International jpournal biological and chemical sciences ISSN 1991-2012.

[15] Botanical Society of Britain and Ireland. Archived from the original (xls) on 2015-012.Retrieved 2014-10- 17.

[16] Flowers of India.

[17] USDA Plants Profile

[18] Henderson, L. (2001). Alien weeds and invasive plants. A complete guide to declared weeds and invaders in South Africa. Plant Protection Research Institute Handbook. PPR, ARC South Africa, 2001, No. 12, pp 300

[19] CABI invasive species compendium online data sheet. Achyranthes aspera (devil's horsewhip). CABI Publishing 2011. www.cabi.org/ISC. Accessed March 2011.

[20] Indian Herbal Pharmacopia Vol. II, Page-5.

[21] Khan, A. V. and A. A. Khan. Ethnomedicinal uses of Achyranthes aspera L. (Amaranthaceae) in management of gynaecological disorders in western Uttar Pradesh (India). Archived at the Wayback Machine Ethnoleaflets, 2010.

[22] Bussmann, R. W.; Gilbreath, G. G.; Solio, J; Lutura, M; Lutuluo, R; Kunguru, K; Wood, N; Mathenge, S. G, "Plant use of the Maasai of Sekenani Valley, Maasai Mara, Kenya". Journal of Ethnobiology and Ethnomedicine, 2006, 2: 22. doi:10.1186/1746-4269-2-22. PMC 1475560. PMID 16674830. 
Comparative Study of Achyranthus Aspera and Phyllanthus Amarus for the Removal of Lead from Polluted Water by using their Biosorbents Powder

[23] J. H. Maiden, The useful native plants of Australia: Including Tasmania. Turner and Henderson, Sydney, 1889

[24] Ved DK and Goraya GS: A Text book of demand and supply of medicinal plants in India. NMPB, New Delhi and FRLHT, Bangalore, India, 2008.

[25] Unander DW, Webster GL and Blumberg BS: Usage and bioassays in Phyllanthus (Euphorbiaceae)-IV: clustering of antiviral uses and other effects. Journal of Ethnopharmacology 1995; 45: 1-18.

[26] "The Plant List: A Working List of All Plant Species". Retrieved June 6, 2014

[27] R Karthik, Angelin C Pushpam, and M. C. Vanitha and D. Yuvaraj. Elimination of Methylene Blue from Aqueous Solution Using Biosorbents under Stirring and Stagnant Conditions. International Journal of Advanced Research in Engineering and Technology, 6(10), 2015, pp. 76-85.

[28] M. Gangadhar, Removal of Lead And Zinc From Wastewater Using Plant Biomass: A Comparative Study, International Journal of Mechanical Engineering and Technology (IJMET), 2018, Volume: 9, Issue: 11, Pages: 1781-1788.

[29] Gaddam Kalyani, Use of a Novel Biosorbent, Pithophora Cleveana Wittrock for the Removal of Lead from Wastewaters-Isothermal Study, International Journal of Mechanical Engineering and Technology, 9(8), 2018, pp. 1049-1060.

[30] Joseph B and Raj SJ: An Overview: Pharmacognostic Property of Phyllanthus amarus International Journal of Pharmacology 2011; 7: 40-45.

[31] Itoro E, Ukana D and Ekaete D: Phytochemical screening and nutrient analysis of Phyllanthus amarus. Asian Journal of Plant Science and Research 2013; 3: 116-122.

[32] Unander DW, Herbert HB, Connete JL and Robert TM: Cultivation of and evaluation of variable potentially affecting yield and the inhibition of viral DNA polymerase. Economic Botany 1993; 47: 79-88. 